\title{
Isolation and quantification of bacterial isolates from citrus fruits and determination of their anti-bacterial activity against selected pathogens
}

\author{
Rowshan Akter, Nusrat Islam Tanu and Md. Aftab Uddin \\ Department of Microbiology, Stamford University Bangladesh, 51 Siddeswari Road, Dhaka \\ 1217, Bangladesh
}

Received 8 November 2013/Accepted 29 November 2013

\begin{abstract}
The present study was undertaken with the aim of investigating the isolation and quantification of microorganisms from the citrus fruit samples collected from different areas of Dhaka city. Out of ten samples studied, the range of total viable bacterial proliferation was approximately $10^{2}$ to $10^{7} \mathrm{cfu} / \mathrm{g}$. Among the specific bacterial pathogens, prevalence of Klebsiella spp. was found in five samples, Listeria spp., Staphylococcus spp. and Pseudomonas spp. in four samples and Vibrio spp. in three samples only. The presumptive identification of these isolates was done by the conventional cultural, microscopic and biochemical tests. Fungal growth was also observed in four samples within the range of $1.2 \times 10^{3}$ to $3.6 \times 10^{3} \mathrm{cfu} / \mathrm{g}$. Interestingly, Prunus mume/domestica (plum) showed the anti-bacterial activity against all the laboratory bacterial isolates tested. Among other samples, Tanarindus bacilus (tamarind) was found to exhibit activity against Escherichia coli, Pseudomonas spp., Salmonella spp., Vibrio spp., and Listeria spp. On the other hand, Monifera indica (mango) showed anti-bacterial efficacy against E. coli, Staphylococcus spp. and Listeria spp. and Citrus limon (lemon) only against Pseudomonas spp. and Listeria spp.
\end{abstract}

Key words: Citrus fruits; Pathogenic bacteria; fungi; Anti-bacterial activity

The term citrus fruit comprises various types of fruits and its related products, principally oranges, accounting for about $70 \%$ of citrus output, and the others including tangerines, mandarins, clementine, satsuma, lemon, lime and grapefruits (1). Because of the fresh-like characteristics and the increasing need of low-caloric food products along with the trait to combat against cardiovascular complications and cancerous transformations, the consumption of citrus fruits and fruit juices has significantly risen over the last few years (2). However, due to inappropriate manipulation during the handling, cutting, shredding, and maintenance of the fruit at ambient temperature and storage conditions, both pathogenic and deteriorative microorganisms may contaminate a product, thus increasing the risk of microbial diseases and spoilage (3). Indeed, the incidence of outbreaks and cases of illness caused by consumption of citrus fruits and unpasteurized juices has increased in the last years (4).

Besides the mass use of antibiotics for the treatment of disease, employment of plant extracts and phytochemicals with the known antimicrobial properties appeared with great impact in the therapeutic treatment process (5-9). Citrus flavonoids are well known to possess a large range of biological activity including anti-bacterial, anti-fungal, anti-diabetic, anti-cancer and

ॠCorresponding Author. Mailing address: Md. Aftab Uddin, Department of Microbiology, Stamford University Bangladesh, 51 Siddeswari Road, Dhaka, Bangladesh; Email: aftab_mb12@yahoo.com. anti-viral activities $(1,10)$. Flavonoids can act as direct antioxidants and free radical scavengers, and have the capacity to modulate enzymatic activities and inhibit cell proliferation (11). In plants, they seem to play a defensive role against invading pathogens, including bacteria, fungi and viruses (12). Preparation from peel, flowers and leaves of bitter orange (Citrus aurantium) are popularly consumed in order to minimize the disorders of central nervous system (13). Citrus fruits have been a matter of interest for the extraction of antimicrobial metabolites by a large number of researchers (14-16). Several studies have shown the antioxidant features of medicinal fruit juices that are rich in phenolic compounds. Natural antioxidants are mainly derived from plants in the form of flavonoid, phenolic acids and tocopherols etc. (17).

Massive use of non-prescribed medicines due to the lack of legislative regulations may trigger the onset of treatment mediated complications related to drugresistance (18). Such a circumstance could stipulate alternative treatment strategies based on natural medication approaches $(19,20)$. In Bangladesh a range of medicinal plants have been identified so far; however, such medicinal properties within the citrus fruits have not still been identified (19). Thus, in the present investigation emphasized not only on the bacterial contamination extent within the citrus fruits but also attempted to measure the anti-bacterial property of different citrus fruits commonly available and readily consumed in Bangladesh. 


\section{MATERIALS AND METHODS}

Study area and sampling. Samples were collected from different local markets of Dhaka city such as Rampura, Shantinagar, Moghbazar and Mailbagh area in different time intervals and transported to the laboratory as soon as possible according to the method suggested earlier (21). For the identification and enumeration of pathogenic bacteria and fungi, at first $10 \mathrm{~g}$ of each sample was taken, then blended with $90 \mathrm{ml}$ normal saline ( $\mathrm{pH}$ 7.8) \& diluted up to $10^{-5}$ (22).

Total viable bacterial count (TVBC), total fungal load and total coliform count (TCC). The enumeration was performed by spreading $0.1 \mathrm{ml}$ sample from the $10^{-5}$ dilution onto nutrient agar (NA) and $0.1 \mathrm{ml}$ from the $10^{-3}$ dilution onto Sabouraud Dextrose Agar (SDA) for the determination of total viable bacterial count (TVBC) and total fungal load, respectively (23). Plates were incubated at $37{ }^{\circ} \mathrm{C}$ for 24 hours and at $25{ }^{\circ} \mathrm{C}$ for 48 hours for TVBC and total fungal load respectively. For the detection of total coliform count (TCC), $0.1 \mathrm{ml}$ sample from the dilution $10^{-3}$ was spread onto MacConkey agar media. The plates were incubated at $37{ }^{\circ} \mathrm{C}$ for 24 hours $(24,25)$. Finally, several biochemical tests were carried out for the final confirmation of coliforms (22).

Isolation of Salmonella spp., Shigella spp., Vibrio spp., Staphylococcus spp. and Pseudomonas spp. An aliquot of $1 \mathrm{ml}$ sample was transferred into each of $9 \mathrm{ml}$ of Selenite Cysteine broth (SCB) and Alkaline Peptone Water (APW) for the enrichment of Salmonella spp., Shigella spp. and Vibrio spp., respectively and incubated at $37^{\circ} \mathrm{C}$ for 6 hours. After enrichment, samples were diluted up to $10^{-4}$ and then $0.1 \mathrm{ml}$ sample from $10^{-2}$ and $10^{-3}$ was spread onto Salmonella-Shigella (SS) agar and Thiosulfate Citrate Bile Salt Sucrose (TCBS) agar (23). Staphylococcus spp. and Pseudomonas spp. were isolated from the Mannitol Salt agar (MSA) and Pseudomonas agar respectively. After incubation at $37{ }^{\circ} \mathrm{C}$ for 24 hours, the typical colony characteristics on these media were observed (24). For further identification, biochemical traits of these isolates were tested following standard methods $(22,26)$

Determination of anti-bacterial activity of the fruit samples. The antibacterial activity of the fruit samples was demonstrated by agar well diffusion method (27). Briefly, fruit blends were used directly on the MuellerHinton agar (MHA) media. At first, the bacterial pathogens (Escherichia coli, Klebsiella spp., Staphylococcus spp., Pseudomonas spp., Salmonella spp., Vibrio spp., and Listeria spp.) were introduced evenly over the MHA separately using cotton swab, followed by making hole $\left(8 \mathrm{~mm}^{3}\right)$ on the MHA by cork borer. Each of the blends was then introduced with the samples (volume of 100 $\mu \mathrm{l}$ with a concentration of $11 \mu \mathrm{g} / \mu \mathrm{l})$ separately in the specified hole with a positive control antibiotic disc- Gentamicin (GEN, $10 \mu \mathrm{g}$ ) and the negative control (normal saline). Presence of clear zone around the sample solution (if any) indicated the presence of antibacterial activity $(28,29)$.

\section{RESULTS AND DISCUSSION}

Most of the fruits are consumed in their raw states and may lead to the onset of human diseases that may put the overall public health at a severe risk (30). Microorganisms are generally associated in a number of ways with the different types of fresh foods affecting the overall quality and health hygiene $(23,31)$. Fruits are contaminated easily with bacterial pathogens by the principle of dissemination of bacterial infection and a single infected citrus fruit can be the root of infection to other fruits during storage and on transport (32). In the present study, the load of Vibrio spp., Salmonella spp. and Shigella spp. were found to be nil before enrichment. However, after enrichment only Vibrio spp. was estimated within a range of $1.8 \times 10^{2}$ to $3.1 \times 10^{2} \mathrm{cfu} / \mathrm{g}$ (Table 1 ). Total viable bacterial count (TVBC) in all the samples observed in this study was within the range of $10^{2}$ to $10^{7}$ $\mathrm{cfu} / \mathrm{g}$. Among the specific pathogens, Klebsiella spp., Staphylococcus spp., Pseudomonas spp., Vibrio spp. and Listeria spp. were biochemically identified (Table 2). Klebsiella spp. was found to exhibit growth in five out of ten samples (Table 1). Surprisingly, both Pseudomonas spp. and Listeria spp. were found to be present only in the sample Phyllanthus emblica (Gooseberry), Ananas comosus (pineapple), Citrus sinensis (malta) and Spondias duscis (ambarella) $\left(\sim 10^{2} \mathrm{cfu} / \mathrm{g}\right)$. The presence of these pathogenic organisms revealed the possibility of spreading enteric diseases to the consumers. On the other hand, fungal load was observed in four samples, all were within the range of $10^{3} \mathrm{cfu} / \mathrm{g}$ (Table 1). Presence of fungus indicates the presence of various mycotoxins in the fruit samples that may pose severe threat to the human health $(33,34)$.

Anti-bacterial activity of the citrus fruit samples. Chemically manufactured medicines may have numerous undesirable side effects on our body but natural antimicrobial agents from the fruits can be used safely in near future as anti-infective pharmaceutical products

TABLE 1. Microbial proliferation in citrus-based fruits samples (cfu/g)

\begin{tabular}{|c|c|c|c|c|c|c|c|}
\hline Sample & TVB & Fungi & $\begin{array}{l}\text { Klebsiella } \\
\text { spp. }\end{array}$ & $\begin{array}{l}\text { Staphylococcus } \\
\text { spp. }\end{array}$ & $\begin{array}{l}\text { Pseudomonas } \\
\text { spp. }\end{array}$ & $\begin{array}{l}\text { Vibrio } \\
\text { spp. }\end{array}$ & $\begin{array}{l}\text { Listeria } \\
\text { spp. }\end{array}$ \\
\hline $\begin{array}{l}\text { Phyllanthus emblica } \\
\text { (Gooseberry) }\end{array}$ & $1.9 \times 10^{6}$ & $1.2 \times 10^{3}$ & 0 & $5.6 \times 10^{3}$ & $6.0 \times 10^{2}$ & 0 & $9.0 \times 10^{2}$ \\
\hline $\begin{array}{c}\text { Prunus mume/domestica } \\
\text { (Plum) }\end{array}$ & $4.0 \times 10^{2}$ & 0 & 0 & 0 & 0 & 0 & 0 \\
\hline $\begin{array}{c}\text { Averrhoa carambola } \\
\text { (Carambola) }\end{array}$ & $2.9 \times 10^{3}$ & 0 & 0 & 0 & 0 & 0 & 0 \\
\hline $\begin{array}{l}\text { Tanarindus bacilus } \\
\text { (Tamarind) }\end{array}$ & $1.2 \times 10^{4}$ & 0 & 0 & 0 & 0 & 0 & 0 \\
\hline $\begin{array}{l}\text { Monifera indica } \\
\text { (Mango) }\end{array}$ & $6.3 \times 10^{7}$ & $3.6 \times 10^{3}$ & $1.9 \times 10^{2}$ & 0 & 0 & $3.1 \times 10^{2}$ & 0 \\
\hline Citrus limon (Lemon) & $7.0 \times 10^{6}$ & $1.9 \times 10^{3}$ & $2.7 \times 10^{2}$ & 0 & 0 & $1.8 \times 10^{2}$ & 0 \\
\hline $\begin{array}{l}\text { Phyllanthus acidus } \\
\text { (Otahe Gooseberry) }\end{array}$ & $7.8 \times 10^{7}$ & $1.9 \times 10^{3}$ & $2.2 \times 10^{2}$ & 0 & 0 & $2.2 \times 10^{2}$ & 0 \\
\hline $\begin{array}{l}\text { Ananas comosus } \\
\text { (Pineapple) }\end{array}$ & $1.6 \times 10^{7}$ & 0 & $5.0 \times 10^{2}$ & $1.5 \times 10^{2}$ & $8.0 \times 10^{2}$ & 0 & $3.5 \times 10^{2}$ \\
\hline Citrus sinensis (Malta) & $1.8 \times 10^{6}$ & 0 & 0 & $7.0 \times 10^{2}$ & $9.0 \times 10^{2}$ & 0 & $2.6 \times 10^{2}$ \\
\hline $\begin{array}{l}\text { Spondias duscis } \\
\text { (Ambarella) }\end{array}$ & $1.7 \times 10^{7}$ & 0 & $2.0 \times 10^{2}$ & $3.0 \times 10^{2}$ & $2.0 \times 10^{2}$ & 0 & $3.0 \times 10^{2}$ \\
\hline
\end{tabular}

Escherichia coli, Salmonella spp. and Shigella spp. were totally absent in all the samples tested. 
TABLE 2. Biochemical identification of different isolates

\begin{tabular}{|c|c|c|c|c|c|c|c|c|c|c|}
\hline \multirow{2}{*}{$\begin{array}{l}\text { Assumed } \\
\text { Organism }\end{array}$} & \multicolumn{3}{|c|}{ TSI } & \multirow{2}{*}{ Ũ } & \multirow{2}{*}{ 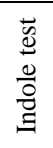 } & \multirow{2}{*}{$\begin{array}{l}\vec{w} \\
\stackrel{\Xi}{a} \\
\stackrel{a}{\Sigma}\end{array}$} & \multirow{2}{*}{$\begin{array}{l}\vec{w} \\
\stackrel{s}{5} \\
\stackrel{5}{a}\end{array}$} & \multirow{2}{*}{ 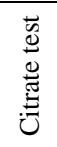 } & \multirow{2}{*}{ 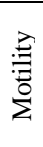 } & \multirow{2}{*}{ 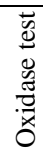 } \\
\hline & Slant & Butt & Gas & & & & & & & \\
\hline Klebsiella spp. & $\mathrm{Y}$ & $\mathrm{Y}$ & + & - & - & - & + & + & - & \\
\hline Vibrio spp & $\mathrm{Y}$ & $\mathrm{Y}$ & - & - & + & + & - & + & + & + \\
\hline Pseudomonas spp. & $\mathrm{R}$ & $\mathrm{R}$ & - & - & - & - & - & + & + & + \\
\hline Staphylococcus spp. & $\mathrm{Y}$ & $\mathrm{R}$ & + & + & - & + & - & + & + & - \\
\hline Listeria $\mathrm{spp}$ & Y & $\mathrm{Y}$ & - & - & - & + & + & - & + & - \\
\hline
\end{tabular}

without creating any bad effects in our body. Antimicrobial activity of various fruits such as guava, orange, dragon fruit, malta, apple, has been experimented around the world in different times (3537).

Interestingly, in the present study, Prunus mume (plum) was found to show the anti-bacterial activity against the entire laboratory isolates of Escherichia coli, Klebsiella spp., Staphylococcus spp., Pseudomonas spp., Salmonella spp., Vibrio spp., and Listeria spp. (Table:3). Among other samples, Tanarindus bacilus (tamarind) exhibited activity against Escherichia coli, Pseudomonas spp., Salmonella spp., Vibrio spp., and Listeria spp. Whereas Monifera indica (mango) were found to be affective against E. coli, Staphylococcus spp. and Listeria spp. (Table: 3). A study conducted by Bansode and Chavan, 2012 (36) in India showed the presence of antimicrobial activity of Citrus limon (lemon) against some enteric pathogens such as E. coli, Salmonella paratyphy B and Shigella sonnei. Surprisingly, in this study no anti-bacterial activity of Citrus limon was found against $E$. coli and most of the other laboratory isolates; however, it showed some degree of activity against Pseudomonas and Listeria spp. (Table 3). Reports on antimicrobial activity of Phyllanthus acidus, Ananas comosus and Citrus sinensis have also been shown by several authors $(38,39)$, but none of these three fruits showed any activity at all in this study. Variation in the antibacterial activity among the different citrus fruits may be due to inappropriate extraction of the active component of some of the samples. Nevertheless, the findings suggest that the citrus fruits may have the potential to play an antimicrobial role against many of the disease causing harmful pathogens.

\section{CONCLUSION}

In fine, it can be concluded that the presence of a wide array of microorganisms with a huge load (near about $10^{7}$ $\mathrm{cfu} / \mathrm{g}$ ) in the different fruit samples is a matter of great concern for the consumers. In addition, a number of pathogenic and indicator bacteria such as Klebsiella spp. in five samples, Listeria spp., Staphylococcus spp. and Pseudomonas spp. in four samples alongwith Vibrio spp. in three samples have been detected. Besides, fungal

TABLE 3. Antimicrobial activity of the citrus fruit samples

\begin{tabular}{|c|c|c|c|c|c|c|c|}
\hline Sample & E. coli & $\begin{array}{c}\text { Klebsiella } \\
\text { spp. }\end{array}$ & $\begin{array}{l}\text { Staphylococcus } \\
\text { spp. }\end{array}$ & $\begin{array}{l}\text { Pseudomonas } \\
\text { spp. }\end{array}$ & $\begin{array}{l}\text { Salmonella } \\
\text { spp. }\end{array}$ & $\begin{array}{l}\text { Vibrio } \\
\text { spp. }\end{array}$ & $\begin{array}{l}\text { Listeria } \\
\text { spp. }\end{array}$ \\
\hline $\begin{array}{c}\text { Phyllanthus emblica } \\
\text { (Gooseberry) }\end{array}$ & 0 & 0 & 0 & 0 & 0 & 0 & 0 \\
\hline Prunus mume (Plum) & $15 \mathrm{~mm}$ & $18 \mathrm{~mm}$ & $15 \mathrm{~mm}$ & $13 \mathrm{~mm}$ & $13 \mathrm{~mm}$ & $13 \mathrm{~mm}$ & $16 \mathrm{~mm}$ \\
\hline $\begin{array}{l}\text { Averrhoa carambola } \\
\text { (Carambola) }\end{array}$ & 0 & 0 & 0 & 0 & 0 & 0 & 0 \\
\hline $\begin{array}{l}\text { Tanarindus bacilus } \\
\text { (Tamarind) }\end{array}$ & $12 \mathrm{~mm}$ & 0 & 0 & $11 \mathrm{~mm}$ & $12 \mathrm{~mm}$ & $12 \mathrm{~mm}$ & $14 \mathrm{~mm}$ \\
\hline Monifera indica (Mango) & $11 \mathrm{~mm}$ & 0 & $13 \mathrm{~mm}$ & 0 & 0 & 0 & $13 \mathrm{~mm}$ \\
\hline Citrus limon (Lemon) & 0 & 0 & 0 & $12 \mathrm{~mm}$ & 0 & 0 & $13 \mathrm{~mm}$ \\
\hline $\begin{array}{c}\text { Phyllanthus acidus (Otahe } \\
\text { Gooseberry) }\end{array}$ & 0 & 0 & 0 & 0 & 0 & 0 & 0 \\
\hline Ananas comosus (Pineapple) & 0 & 0 & 0 & 0 & 0 & 0 & 0 \\
\hline Citrus sinensis (Malta) & 0 & 0 & 0 & 0 & 0 & 0 & 0 \\
\hline Spondias duscis (Ambarella) & 0 & 0 & 0 & 0 & 0 & 0 & 0 \\
\hline $\begin{array}{c}\text { Positive control } \\
\text { (Gentamicin, GEN- } 10 \mu \mathrm{g})\end{array}$ & $25 \mathrm{~mm}$ & $26 \mathrm{~mm}$ & $27 \mathrm{~mm}$ & $26 \mathrm{~mm}$ & $25 \mathrm{~mm}$ & $26 \mathrm{~mm}$ & $27 \mathrm{~mm}$ \\
\hline $\begin{array}{c}\text { Negative control } \\
\text { (Normal saline) }\end{array}$ & 0 & 0 & 0 & 0 & 0 & 0 & 0 \\
\hline
\end{tabular}


growth was also observed in a number of samples. Further study is required to detect the antibiotic resistance pattern of the isolates detected from the commonly consumed citrus fruits which is of significance from the view point of public health. Another aspect of the present study was the detection of anti-bacterial activity of the samples against most of the laboratory isolates tested (within a zone of inhibition of minimum $11 \mathrm{~mm}$ to a maximum of $16 \mathrm{~mm}$ ). This indicates that the citrus fruits can be a potential alternative to the conventional commercially available antibiotics found in the market. So different extraction methods need to be standardized to find out the best one before using citrus fruits as therapeutic agents. Every possible measure should be taken by the different regulatory bodies to ensure the safe consumption of fruits.

\section{ACKNOWLEDGEMENTS}

We thank Stamford University Bangladesh for the technical facilities and financial support.

\section{REFERENCES}

1. Mathur, A., et al. 2011. Evaluation of in vitro antimicrobial \& antioxidant activity of peels \& pulp of some citrus species. IJPI'S Journal of Biotechnology and Biotherapeutics 1 (2): 2229-2278.

2. Rico, D., A. B. Mart'ın-Diana, J. M. Barat, and C. Barry-Ryan. 2007. Extending and measuring the quality of fresh-cut fruit and vegetables: a review. Trends Food Sci. Technol. 18: 373-86.

3. Beuchat, L. R. 1996. Pathogenic microorganisms associated with fresh produce. J. Food Prot. 59 (2): 204-216.

4. Harris, L. J., et al. 2003. Outbreaks associated with fresh produce: incidence, growth, and survival of pathogens in fresh and fresh-cut produce. CRFSFS 2 (1): 78-141.

5. Chanda, S., Y. Baravalia, M. Kaneria, and K. Rakholiya. 2010. Fruit and vegetable peels - strong natural source of antimicrobics. Current Research Technology and Education Topics in Applied Microbiology and Microbial Biotechnology. A. Mendez-Vilas: 444-450.

6. Tyagi, A. K., and A. Malik. 2010. Liquid and vapour-phase antifungal activities of selected essential oils against Candida albicans. BMC Complem. Altern. Med. 10: 65 .

7. Seenivasan, P., J. Manickkam, and I. Savarimuthu. 2006. In vitro antibacterial activity of some plant essential oils. BMC Complem. Altern. Med. 6: 39 .

8. Saadi, M. A. K., H. A. M. Salih, and A. M. Abbas. 2003. Study of the fruit peels of Citrus sinesis \& Punica granatum. Journal of Babylon University 3 (9): 243-342.

9. Gislene, G. F., N. J. Locatelli, C. F. Paulo, and L. S. Giuliana. 2000. Antibacterial activity of plant extracts and phytochemicals on antibiotic resistant bacteria. Braz. J. Microbiol. 31: 247-256.

10. Ahmed, A. 2006. Genetic variability to essential oil composition in four Citrus fruit species. Pak. J. Bot. 38 (2): 319-324.

11. Duthie, G., and A. Crozier. 2000. Plant-derived phenolic antioxidants. Curr. Opin. Lipidol. 11: 43-47.

12. Sohn, H. Y., K. H. Son, C. S. Know, and S. S. Kang. 2004. Antimicrobial and cytotoxic activity of 18 prenylated flavonoids isolated from medicinal plants: Morus alba L., Morus mongolica Schneider, Broussnetia papyrifera (L.) Vent, Sophora flavescens Ait and Echinosophora koreensis Nakai. Phytomedicine 11: 666-672.

13. Pultrini, A. M., L. A. Galindo, and M. Costa. 2006. Effects of the essential oil from Citrus aurantium in experimental anxiety models in mice. Life Sci. 78 (15): 1720-1725.
14. Kumar, A. K., A. Subanthini, and M. Jayakumar. 2011. Antimicrobial activity and phytochemical analysis of citrus fruit peels -utilization of fruit waste 3 (6): 5414-5421.

15. Kumar, V. R. 2010. Anti-typhoid activity of aqueous extract of fruit peel Citrus sinensis (L.).Intl. J. Pharm. Res. Dev. 2 (9): 217-221.

16. Singh, A., and A. R. Bilal. 2009. In vitro antibiotic activity of isolated volatile oil of Citrus sinensis. Intl. J. Pharm. Res. Dev. 7 (1): 1-4.

17. Ghasemi, K., Y. Ghasemi, and M. A. Ebrahimzadeh. 2009. Antioxidant Activity, Phenol and Flavonoid contents of 13 citrus species peels and tissues. Pak. J. Pharm. Sci. 22 (3): 277-281

18. Dutta, S., et al. 2013. Study of antimicrobial susceptibility of clinically significant microorganisms isolated from selected areas of Dhaka, Bangladesh. Bang. J Med Sci. 12 (1): 34-42

19. Akter, S., et al. 2012. A selection of medicinal plants used as blood purifiers by folk medicinal practitioners of Bangladesh. American-Eurasian Journal of Sustainable Agriculture 6 (3): 188-194.

20. Veeresham, C., and P. Chitti. 2013. Therapeutic agents from tissue cultures of medicinal plants. Nat. Prod. Chem. Res. 1: 118

21. American Public Health Association (APHA). 1998. Standard methods for the examination of water and wastewater. American Public Health Association, Washington, D.C.

22. Cappuccino, J. G., and N. Sherman. 1996. Microbiology - A Laboratory Manual. The Benjamin/Cummings Publishing Co., Inc., Menlo Park, California.

23. Rahman, F., and R. Noor. 2012. Prevalence of pathogenic bacteria in common salad vegetables of Dhaka metropolis. Ban. J. Bot. 41 (2): 150-162.

24. Noor, R., et al. 2013. Microbiological study of major sea fish available in local markets of Dhaka city, Bangladesh. J. Microbiol. Biotechnol. Food Sci. 2 (4): $2420-2430$

25. Acharjee, et al. 2013. Microbiological study of vendor and packed fruit juices locally available in Dhaka city, Bangladesh. International Food Research Journal. 20 (2): 1017 - 1022

26. Alfrad, E. B. 2007. Bensons Microbiological Applications. Mcgraw-Hill Book Company, New York.

27. Bauer, A. W., W. M. M. Kirby, J. C. Sherris, and M. Tierch. 1998. Antibiotic susceptibility testing by a standardized single disc method. Am. J. Clin. Pathol. 45 (4): 493-496, 1998.

28. Jagessar, R. C., A. Mars, and G. Gones. 2008. Selective antimicrobia properties of leaf extract against various micro-organisms using Disc diffusion and Agar well diffusion method. J. Nat. Sci. 6 (2): 24-38.

29. Hussain, A., S. Wahab, I. Zarin, and M. D. S. Hussain. 2010. Antibacterial activity of the leaves of Coccinia indica (W. and A) of India. Adv. Biol. Res. 4 (5): 241-248.

30. Butt, A. A., K. E. Aldridge, and C. V. Sanders. 2004. Infections related to the ingestion of seafood part 1: viral and bacterial infections. Lancet Infect. Dis. 4: 201-212.

31. Feroz, F., J. D. Senjuti, and R. Noor. 2013. Determination of microbial growth and survival in salad vegetables through in vitro challenge test. Int. J. Nutri. Food Sci. 2 (6): 312-319.

32. Jay, J. M. 2003. Microbial Spoilage of Food. In Modern Food Microbiology, $4^{\text {th }}$ ed. Chapman and Hall Inc. New York.

33. Reddy, K. R. N., et al. 2010. An overview of mycotoxin contamination in foods and its implications for human health. Toxin Reviews 29 (1): 3-26

34. Dimitrios, I. T., M. Ddimakopoulou, P. P. Antoniou, and C. T. Eleftherios 2012. Biological control strategies of mycotoxigenic fungi and associated mycotoxins in Mediterranean basin crops. Phytopathologia Mediterranea 51 (1): $158-174$

35. Malaviya, A., and N. Mishra. 2011. Antimicrobial activity of tropical fruits Biological Forum - An International Journal 3 (1): 1-4.

36. Bansode, D. S., and M.D. Chavan. 2012. Studies on antibacterial activity and phytochemical analysis of citrus fruit juices against selected enteric pathogens. International Research Journal of Pharmacy 3 (11): 122-126.

37. Fatema, N., M. Acharjee, and R. Noor. 2013. Microbiological Profiling of Imported Apples and Demonstration of Bacterial Survival Capacity through in vitro Challenge Test. American Journal of Microbiological Research 1 (4): 98104.

38. Devi, S. S., and S. B. Paul. 2011. An overview on Cicca acida (Phyllanthus acidus). Assam University Journal of Science \& Technology: Biological and Environmental Sciences 7 (1): 156-160.

39. Bansode, D. S., and M. D. Chavan. 2013. Evaluation of Antimicrobial activity and phytochemical analysis of papaya and pineapple fruit juices against selected enteric pathogens. Int J Pharm Bio Sci. 4 (2): 1176 - 1184. 